\title{
PROFESSIONAL PLACEMENT SERVICE 1994 ANNUAL MEETING
}

APSA will sponsor a Professional Placement Service at the Sheraton New York Hotel, during the 1994 Annual Meeting in New York City. The Placement Service will be open from 8:00 a.m. to 6:00 p.m. on Thursday thru Saturday, September 1-3; and from 9:00 a.m. to Noon on Sunday, September 4.

Facilities will be available to review job listings and resumes, exchange messages, and conduct interviews. To register for the Placement Service and obtain Employer Forms (Job Orders) or Application (Candidate) Forms, please complete and mail the form below as soon as possible, but no later than July 26 . 1994. Employer and/or Candidate forms will be forwarded to you upon receipt of your request.

CANDIDATES WHO DO NOT REgISTER FOR THE PLACEMENT SERVICE BEFORE THE MEETING WIL BE CHARGED \$10.00 TO REGISTER AT THE MEETING. Employers whose Departments are not members of the APSA Departmental Services Program will be charged a Placement Service Fee of $\$ 100.00$ (PREPAID). All persons using the Placement Service are required to register for the 1994 Annual Meeting.

PLACEMENT SERVICE PRE-REgISTRATION IS STRONGLY RECOMMENDED.

Please RUSH me the forms I have checked below!

Name:

Mailing Address:

City: State: Zip:

Organization or Department:

Candidate $\square$ Employer Number of Positions

Mail to:

1994 Annual Meeting Professional Placement Service American Political Science Association

1527 New Hampshire Avenue, N.W. Washington, D.C. 20036 